\title{
Variation of the T Lymphocytes According to Treatment in Breast Cancer
}

\author{
ANCA ZGURA ${ }^{1}$, LAURENTIA GALES ${ }^{1}$, ELVIRA BRATILA ${ }^{1}$, CLAUDIA MEHEDINTU1*, BOGDAN HAINEALA ${ }^{1}$, \\ RAMO NA ILEANA BARAC ${ }^{1}$, AMORIN REMUS POPA², CAMELIA BUHAS ${ }^{2}$, COSTIN BERCEANU ${ }^{3}$, CRISTINA VERONICA ANDREESCU $^{1}$, \\ RODICA ANGHEL ${ }^{1}$ \\ ${ }^{1}$ Carol Davila University of Medicine and Pharmacy, 8 Eroii Sanitari Str., 050474, Bucharest, Romania \\ 2 University of Oradea, Faculty of Medicine and Pharmacy, 1 Universitatii Str., 410087, Oradea, Romania \\ 3 University of Medicine and Pharmacy, 2 Petru Rares, 200349, Craiova, Romania
}

\begin{abstract}
Breast cancer is a multifaceted disease whose varied phenotype recapitulates only partially the biological complexity. At present, there are new approaches to the diagnosis and treatment of this form of cancer, but research should also focus on identifying and implementing other individual prognostic factors, factors that may lead to improved clinical decision making with regard to the patient, in order to establish an individualized treatment.
\end{abstract}

\section{Keywords: breast cancer, T-lymphocytes, chemotherapy, radiotherapy, hormonal therapy}

Breast cancer is a multifaceted disease whose varied phenotype recapitulates only partially the biological complexity.

Due to very high absolute levels of incidence and, inevitably, mortality, breast cancer is one of the major forms of both prevention and treatment and, not for the sake of scientific research. Numerous efforts have been made over time to improve the survival rate through early diagnosis and multiple (combined) therapies. At present, there are new approaches to the diagnosis and treatment of this form of cancer, but research should also focus on identifying and implementing other individual prognostic factors, factors that may lead to improved clinical decision making with regard to the patient, in order to establish an individualized treatment.

Immunoediting is a dynamic process that consists of immunosuppression and tumor progression. Tumor progression has 3 phases: elimination, equilibrium and escape. In the elimination and balance phases, cancer cells are attacked by the CD8 + T lymphocytes, while the tumor escape phase inhibits the CD8 + T lymphocytes.

\section{Experimental part}

In order to better understand the effects of the treatment on the adaptive immune system, peripheral blood samples were collected from 50 patients diagnosed and treated at the Bucharest Prof. Dr. Alexandru Trestioreanu Oncological Institute, during 2012-2018, to determine the influence of T lymphocytes on tumor progression as possible prognostic factors in relation to the clinical and pathological parameters and their response to the adjuvant / neoadjuvant, hormonal or radiotherapy treatment.

Chemotherapy regimens were established according to the ESMO and NCCN guidelines.

The 50 patients included in the study underwentadjuvant cytostatic and neoadjuvant chemotherapy consisting of EC chemotherapy (Epirubicin $90 \mathrm{mg} / \mathrm{m} 2$ IV, Cyclophosphamide $600 \mathrm{mg} / \mathrm{m} 2 \mathrm{IV}$ ) followed by Docetaxel $100 \mathrm{mg} / \mathrm{m}^{2}$, CMF type (Cyclophosphamide $600 \mathrm{mg}$ / Methotrexate $40 \mathrm{mg} / \mathrm{m} 2$ IV, 5-Fluorouracil $600 \mathrm{mg} / \mathrm{m} 2 \mathrm{IV}$ followed by Docetaxel $100 \mathrm{mg} / \mathrm{m}^{2} \mathrm{IV}$ administered every 21 days) or FEC chemotherapy (5-Fluorouracil $500 \mathrm{mg} /$ $\mathrm{m}^{2} \mathrm{IV}$, Epirubicin $100 \mathrm{mg} / \mathrm{IV}$, Cyclophosphamide $600 \mathrm{mg} /$ $\mathrm{m}^{2}$ IV, administered every 21 days) followed by Docetaxel ( $100 \mathrm{mg} / \mathrm{m} 2 \mathrm{IV}$, given every 21 days). Patients who had positive hormonal receptors follow ed hormone treatment
(Tamoxifen or Anastrozole). For patients confirmed with Her2 in the IHC (7 patients), Trastuzumab $(6 \mathrm{mg} / \mathrm{kg}$ IV every 21 days for 1 year) could be given. Of the total patients, 20 representing $35.71 \%$ performed radiotherapy. Table 1 presents the statistical correlation between age and lymphocite $T$ values.

Age is negatively correlated with the total CD3 T lymphocytes $(-0.012)$, but statistically significant.

Age is negatively correlated with CD4 + T $(-0.102)$, statistically insignificant, i.e. younger patients have elevated CD3 + CD4 + T values. CD8 $(-0.256)$ is correlated with age, has a poor but statistically significant correlation, suggesting that younger patients have higher CD8 + T values. The statistical correlation between age and ratio is only $10 \%$, suggesting that older patients have a higher CD4 / CD8 ratio.

Table 2-4 shows the maximum and minimum values of analyzed T lymphocytes at the I, II, and III evaluation.

The first evaluation was performed on a total of 15 patients with the following lymphocyte counts:

-For CD3 + T, the minimum value was $24.18 \%$, the maximum value was $75.13 \%$ and the average value was $52.77 \%$.

-For CD4 + T the minimum value was $13.35 \%$, the maximum value was $42.30 \%$ and the average value was $28.58 \%$.

- For CD8 + T the minimum value was 8.08 , the maximum value was 19.81 and the average value was 19.81.

-For the CD4 + / CD8 + ratio the average value was 1.61 (minimum 0.71 and maximum 4.65).

A second evaluation was performed on a number of 15 patients who had the following values:

-For CD3 + T, the minimum value was $22.99 \%$, the maximum value was $68.44 \%$ and the average value was $50.28 \%$.

- For CD4 + T the minimum value was $10.84 \%$, the maximum value was $44.03 \%$ and the average value was $27.23 \%$.

- For CD8 + T the minimum value was $8.85 \%$, the maximum value was $32.05 \%$ and the average value was $19.56 \%$.

- For the CD4 + / CD8 + ratio, the mean value was 1.61 (minimum value 0.76 and maximum value 4.25 )

For the evaluation we had a total of 4 patients who had the following values: 
Table 1

STATISTICAL CORRELATION BETWEEN AGE AND LYMPHOCYTE T VALUES

\begin{tabular}{|c|c|c|c|c|c|c|c|c|}
\hline \multicolumn{2}{|c|}{ LYMPHOCYTE T } & CD3.1 & CD4.1 & CD8.1 & DP.1 & DN.1 & CD4 CD8.1 & Age \\
\hline \multirow[t]{3}{*}{ CD3.1 } & Correlation Coefficient & 1.000 & $.510^{\text {क* }}$ & $.512^{\text {*2* }}$ & .180 & .182 & -.097 & $-.212^{*}$ \\
\hline & Sig. (2-tailed) & & .000 & .000 & .066 & .063 & .323 & .031 \\
\hline & $\mathrm{N}$ & 50 & 50 & 50 & 50 & 50 & 50 & 50 \\
\hline \multirow[t]{3}{*}{ CD4.1 } & Correlation Coefficient & $.510^{4 *}$ & 1.000 & .078 & -.073 & .042 & $.348^{4+2}$ & -.102 \\
\hline & Sig. (2-tailed) & .000 & & .427 & .456 & .670 & .000 & .299 \\
\hline & $\mathrm{N}$ & 50 & 50 & 50 & 50 & 50 & 50 & 50 \\
\hline \multirow[t]{3}{*}{ CD8.1 } & Correlation Coefficient & $.512^{\text {क्स }}$ & .078 & 1.000 & .119 & .088 & $-.575^{-4}$ & $-.256^{24}$ \\
\hline & Sig. (2-tailed) & .000 & .427 & & .225 & .371 & .000 & .009 \\
\hline & $\mathrm{N}$ & 50 & 50 & 50 & 50 & 50 & 50 & 50 \\
\hline \multirow[t]{3}{*}{ DP.1 } & Correlation Coefficient & .180 & -.073 & .119 & 1.000 & .080 & -.162 & .003 \\
\hline & Sig. (2-tailed) & .066 & .456 & .225 & & .417 & .099 & .973 \\
\hline & $\mathrm{N}$ & 50 & 50 & 50 & 50 & 50 & 50 & 50 \\
\hline \multirow[t]{3}{*}{ DN.1 } & Correlation Coefficient & .182 & .042 & .088 & .080 & 1.000 & -.030 & $-.198^{*}$ \\
\hline & Sig. (2-tailed) & .063 & .670 & .371 & .417 & & .757 & .044 \\
\hline & $\mathrm{N}$ & 50 & 50 & 50 & 50 & 50 & 50 & 50 \\
\hline \multirow[t]{3}{*}{ CD4_CD8.1 } & Correlation Coefficient & -.097 & $.348^{40}$ & $-.575^{-4}$ & -.162 & -.030 & 1.000 & .170 \\
\hline & Sig. (2-tailed) & .323 & .000 & .000 & .099 & .757 & & .085 \\
\hline & $\mathrm{N}$ & 50 & 50 & 50 & 50 & 50 & 50 & 50 \\
\hline \multirow[t]{3}{*}{ Age } & Correlation Coefficient & $-.212^{*}$ & -.102 & $-.256^{* 4}$ & .003 & $-.198^{\circ}$ & .170 & 1.000 \\
\hline & Sig. (2-tailed) & .031 & .299 & .009 & .973 & .044 & .085 & \\
\hline & $\mathrm{N}$ & 50 & 50 & 50 & 50 & 50 & 50 & 56 \\
\hline
\end{tabular}

\begin{tabular}{|c|c|c|c|c|}
\hline LYMPHOCYTE T & Minimum & Maximum & Mean & Std. Dev. \\
\hline CD3.1 & 24.18 & 75.13 & 52.77 & 10.31 \\
\hline CD4.1 & 13.35 & 42.30 & 28.58 & 6.98 \\
\hline CD8.1 & 8.08 & 30.84 & 19.81 & 6.30 \\
\hline DP.1 & .12 & 9.41 & 1.32 & 1.60 \\
\hline DN.1 & .60 & 8.12 & 2.86 & 1.80 \\
\hline CD4_CD8.1 & .71 & 4.65 & 1.61 & 0.79 \\
\hline
\end{tabular}

Table 2

MAXIMUM AND MINIMUM VALUES OF ANALYZED T LYMPHOCYTES

(I EVALUATION) $(\mathrm{N}=50)$

\begin{tabular}{|c|c|c|c|c|}
\hline LYMPHOCYTE T & Minimum & Maximum & Mean & Std. Dev. \\
\hline CD3.2 & 22.99 & 68.44 & 50.28 & 13.01 \\
\hline CD4.2 & 10.84 & 44.03 & 27.23 & 7.79 \\
\hline CD8.2 & 8.85 & 32.05 & 19.56 & 7.70 \\
\hline DP.2 & .22 & 2.29 & 1.02 & 0.78 \\
\hline DN.2 & .51 & 6.53 & 2.47 & 1.90 \\
\hline CD4_CD8.2 & .76 & 4.25 & 1.61 & 0.91 \\
\hline Valid N(listwise) & - & - & - & - \\
\hline
\end{tabular}

Table 3

MAXIMUM AND MINIMUM VALUES OF ANALYZED T LYMPHOCYTES (II EVALUATION) $(\mathrm{N}=15)$
- For $\mathrm{CD} 3+\mathrm{T}$, the minimum value was $11.42 \%$, the maximum value was $71.11 \%$ and the average value was $45.76 \%$.

- For CD4 + T, the minimum value was $11.42 \%$, the maximum value was $38.61 \%$ and the average value was $25.67 \%$.

- For CD8 + T the minimum value was $9.21 \%$, the maximum value was $29.55 \%$ and the average value was $17.15 \%$.

- For the CD4 + / CD8 + ratio the average value was 1.75 (minimum value 0.84 and maximum 3.71 ).
Table 5 depicts the average values for patients with 2 evaluations.

For CD3 + T the mean value was $50.89 \%$. For CD4 + T mean value was $28.04 \%$.

For CD8 + T the mean value was $19.68 \%$. For the CD4 + / CD8 + ratio, the mean value was 1.61 .

Table 6 shows the statistical correlation between $T$ lymphocyte evaluations.

The first and second evaluations are strongly correlated statistically positive $(p<0.05)$ (table 7$)$. 


\begin{tabular}{|c|c|c|c|c|c|}
\hline LYMPHOCYTE T & $\mathrm{N}$ & Minimum & Maximum & Mean & Std. Deviation \\
\hline CD3.3 & 4 & 25.86 & 71.11 & 45.76 & 18.85 \\
\hline CD4.3 & 4 & 11.42 & 38.61 & 25.67 & 12.85 \\
\hline CD8.3 & 4 & 9.21 & 29.55 & 17.15 & 8.76 \\
\hline DP.3 & 4 & .78 & 3.77 & 1.68 & 1.41 \\
\hline DN.3 & 4 & 1.37 & 2.05 & 1.87 & 0.34 \\
\hline CD4_CD8.3 & 4 & .84 & 3.71 & 1.75 & 1.32 \\
\hline
\end{tabular}

Table 4

MAXIMUM AND MINIMUM VALUES OF ANALYZED T LYMPHOCYTES (III EVALUATION)

\begin{tabular}{|l|c|c|c|c|}
\hline \multicolumn{2}{|c|}{ Paired Samples Statistics } & Mean & Std. Deviation & Std. Error Mean \\
\hline \multirow{2}{*}{ Pair 1 } & CD3.1 & 50.8920 & 7.1348 & 1.8422 \\
\cline { 2 - 5 } & CD3.2 & 50.2793 & 13.0109 & 3.3594 \\
\hline \multirow{2}{*}{ Pair 2 } & CD4.1 & 28.0480 & 6.4588 & 1.6676 \\
\cline { 2 - 5 } & CD4.2 & 27.2293 & 7.7876 & 2.0107 \\
\hline \multirow{2}{*}{ Pair 3 } & CD8.1 & 19.6840 & 6.0553 & 1.5635 \\
\cline { 2 - 5 } & CD8.2 & 19.5640 & 7.6994 & 1.9880 \\
\hline \multirow{2}{*}{ Pair 4 } & DP.1 & .9853 & 0.9929 & 0.2564 \\
\cline { 2 - 5 } & DP.2 & 1.0247 & 0.7801 & 0.2014 \\
\hline \multirow{2}{*}{ Pair 5 } & DN.1 & 2.1807 & 1.2990 & 0.3354 \\
\cline { 2 - 5 } & DN.2 & 2.4733 & 1.8966 & 0.4897 \\
\hline \multirow{2}{*}{ Pair 6 } & CD4_CD8.1 & 1.6413 & 0.9646 & 0.2491 \\
\cline { 2 - 5 } & CD4_CD8.2 & 1.6140 & 0.9110 & 0.2352 \\
\hline
\end{tabular}

Table 5

AVERAGE VALUES FOR PATIENTS WITH 2 EVALUATIONS $(\mathrm{N}=15)$

\begin{tabular}{|l|l|c|c|c|}
\hline \multicolumn{2}{|l|}{ Paired Samples Correlations } & N & Correlation & Sig. \\
\hline Pair 1 & CD3.1 \& CD3.2 & 15 & .436 & .104 \\
\hline Pair 2 & CD4.1 \& CD4.2 & 15 & .602 & .018 \\
\hline Pair 3 & CD8.1 \& CD8.2 & 15 & .700 & .004 \\
\hline Pair 4 & DP.1 \& DP.2 & 15 & .800 & .000 \\
\hline Pair 5 & DN.1 \& DN.2 & 15 & .944 & .000 \\
\hline Pair 6 & CD4_CD8.1 \& CD4_CD8.2 & 15 & .899 & .000 \\
\hline
\end{tabular}

Table 6

STATISTICAL CORRELATION BETWEEN T LYMPHOCYTE EVALUATIONS

CORRELATION BETWEEN EVALUATIONS

\begin{tabular}{|c|c|c|c|c|c|c|c|c|c|}
\hline \multirow{3}{*}{\multicolumn{2}{|c|}{ Paired Samples Test }} & \multicolumn{5}{|c|}{ Paired Differences } & \multirow{3}{*}{$\mathrm{t}$} & \multirow{3}{*}{ df } & \multirow{3}{*}{$\begin{array}{l}\text { Sig. (2- } \\
\text { tailed) }\end{array}$} \\
\hline & & \multirow{2}{*}{ Mean } & \multirow{2}{*}{$\begin{array}{c}\text { Std. } \\
\text { Deviation }\end{array}$} & \multirow{2}{*}{$\begin{array}{l}\text { Std. Error } \\
\text { Mean }\end{array}$} & \multicolumn{2}{|c|}{$\begin{array}{l}95 \% \text { Confidence Interval } \\
\text { of the Difference }\end{array}$} & & & \\
\hline & & & & & Lower & Upper & & & \\
\hline Pair 1 & CD 3.1-CD3.2 & .61267 & 11.79969 & 3.04667 & -5.92179 & 7.14712 & .201 & 14 & .844 \\
\hline Pair 2 & CD4.1-CD4.2 & .81867 & 6.46429 & 1.66907 & -2.76114 & 4.39847 & .490 & 14 & .631 \\
\hline Pair 3 & CD8.1-CD 8.2 & .12000 & 5.53504 & 1.42914 & -2.94520 & 3.18520 & .084 & 14 & .934 \\
\hline Pair 4 & DP.1-DP.2 & -.03933 & .59629 & .15396 & -.36955 & .29088 & -.255 & 14 & .802 \\
\hline Pair 5 & DN.1-DN.2 & -.29267 & .79686 & .20575 & -.73395 & .14862 & -1.422 & 14 & .177 \\
\hline Pair 6 & $\begin{array}{l}\text { CD4_CD8.1- } \\
\text { CD4_CD 8.2 } \\
\end{array}$ & .02733 & .42570 & .10992 & -.20841 & .26308 & .249 & 14 & .807 \\
\hline
\end{tabular}

Table 8

MEAN T LYMPHOCYTE FOR PATIENTS UNDERGOING HORMONAL TREATMENT ( $\mathrm{N}=34$ )

\begin{tabular}{|c|c|c|c|c|c|}
\hline $\begin{array}{c}\text { LYMPHOCYTE } \\
\text { T }\end{array}$ & Range & Minimum & Maximum & Mean & Std. Deviation \\
\hline CD3 (\%) & 50.95 & 24.18 & 75.13 & 53.5079 & 11.09944 \\
\hline CD4 (\%) & 28.95 & 13.35 & 42.30 & 28.1724 & 6.97379 \\
\hline CD8 (\%) & 23.97 & 8.08 & 32.05 & 20.6638 & 6.63040 \\
\hline CD4/CD8 & 2.236793 & 0.709654 & 2.946447 & 1.494621 & 0.562676 \\
\hline
\end{tabular}

Of all the patients, 34 are hormone-treated and the mean values for CD4 + T were $28.17 \%$, for CD8 + T $20.66 \%$ and a value of 1.49 .

In the group of patients undergoing radiotherapy, the mean values for CD4 + T were $31.55 \%$, for CD8 + T it was $17.06 \%$ and the CD4 / CD8 ratio was 2.5.

For the patients undergoing $\mathrm{CHT}+$ Transtuzumab treatment the mean value for CD4 + T was 23.78, for CD8 + T 16.73 and the ratio of 1.48 (table 10). Table 11 shows the results for the statistical correlation of T Iymphocyte values in patients undergoing hormone and radiotherapy. Table 12 presents the mean values of T Iymphocyte in the case of the patients undergoing treatment with Transtuzumab + HT and RT.

From a statistical point of view, there is no statistical difference between the CD4 + T and CD8 + T values in the group of patients undergoing hormone treatment and those undergoing radiotherapy. 


\begin{tabular}{|l|r|r|r|r|r|}
\hline $\begin{array}{c}\text { LYMPHOCYTE } \\
\text { T }\end{array}$ & \multicolumn{1}{|c|}{ Range } & \multicolumn{1}{c|}{ Minimum } & Maximum & \multicolumn{1}{c|}{ Mean } & \multicolumn{1}{c|}{ Std. Deviation } \\
\hline CD3 (\%) & 12.97 & 47.39 & 60.36 & 52.3383 & 4.35802 \\
\hline CD4 (\%) & 19.46 & 22.46 & 41.92 & 31.5567 & 8.26869 \\
\hline CD8 (\%) & 20.19 & 8.58 & 28.77 & 17.0617 & 8.58743 \\
\hline CD4/CD8 & 3.785372 & 0.909267 & 4.694639 & 2.515384 & 1.772185 \\
\hline
\end{tabular}

\begin{tabular}{|c|c|c|c|c|c|}
\hline $\begin{array}{c}\text { LYMPHOCYTE } \\
\text { T }\end{array}$ & Range & Minimum & Maximum & Mean & Std. Deviation \\
\hline CD3 (\%) & 32.97 & 22.99 & 55.96 & 43.9856 & 11.24280 \\
\hline CD4 (\%) & 20.26 & 10.84 & 31.10 & 23.7844 & 7.46628 \\
\hline CD8 (\%) & 15.67 & 8.85 & 24.52 & 16.7333 & 5.19339 \\
\hline CD4/CD8 & 1.721059 & 0.950762 & 2.671821 & 1.480460 & 0.521595 \\
\hline
\end{tabular}

\begin{tabular}{|l|l|c|c|c|c|}
\hline \multicolumn{6}{|l|}{ Group Statistics } \\
\hline RT/HT & $\mathrm{N}$ & Mean & Std. Deviation & Std. Error Mean \\
\hline CD4 (\%) & 3 & 6 & 31.5567 & 8.26869 & 3.37568 \\
\cline { 2 - 6 } & 9 & 34 & 28.1724 & 6.97379 & 1.19599 \\
\hline CD8 (\%) & 3 & 6 & 17.0617 & 8.58743 & 3.50580 \\
\cline { 2 - 6 } & 9 & 34 & 20.6638 & 6.63040 & 1.13710 \\
\hline CD4/CD8 & 3 & 6 & 2.5154 & 1.77218 & 0.72349 \\
\cline { 2 - 6 } & 9 & 34 & 1.4946 & 0.56268 & 0.09650 \\
\hline
\end{tabular}

Table 9

MEAN VALUES OF T LYMPHOCYTE FOR PATIENTS UNDERGOING RADIOTHERAPY $(\mathrm{N}=6)$

Table 10

MEAN VALUES OF T LYMPHOCYTE FOR PATIENTS UNDERGOING TREATMENT WITH TRANSTUZUMAB

\begin{tabular}{|c|c|c|c|c|c|}
\hline \multicolumn{2}{|c|}{$\begin{array}{c}\text { LYMPHOCYTE } \\
\text { T }\end{array}$} & N & Mean & Std. Deviation & Std. Error Mean \\
\hline CD4 (\%) & 2 & 9 & 23.7844 & 7.46628 & 2.48876 \\
\cline { 2 - 6 } & 3 & 6 & 31.5567 & 8.26869 & 3.37568 \\
\hline CD8 (\%) & 2 & 9 & 16.7333 & 5.19339 & 1.73113 \\
\cline { 2 - 6 } & 3 & 6 & 17.0617 & 8.58743 & 3.50580 \\
\hline CD4/CD8 & 2 & 9 & 1.48046 & 0.52160 & 0.17387 \\
\cline { 2 - 6 } & 3 & 6 & 2.51538 & 1.77218 & 0.72349 \\
\hline
\end{tabular}

\section{Table 11}

STATISTICAL CORRELATION OF T LYMPHOCYTE VALUES IN PATIENTS UNDERGOING HORMONE TREATMENT AND RADIOTHERAPY

Table 13

STATISTICAL CORRELATION OF T LYMPHOCYTE VALUES IN PATIENTS RECEIVING HT AND RT TREATMENT

\begin{tabular}{|c|c|c|c|c|c|c|c|c|c|c|}
\hline \multirow{3}{*}{\multicolumn{2}{|c|}{ LYMPHOCYTE T }} & \multicolumn{2}{|c|}{$\begin{array}{l}\text { Levene's Test for } \\
\text { Equality of } \\
\text { Variances }\end{array}$} & \multicolumn{7}{|c|}{ t-test for Equality of Means } \\
\hline & & \multirow[b]{2}{*}{ F } & \multirow[b]{2}{*}{ Sig. } & & \multirow[b]{2}{*}{ df } & \multirow{2}{*}{$\begin{array}{l}\text { Sig. (2- } \\
\text { tailed) }\end{array}$} & \multirow{2}{*}{$\begin{array}{c}\text { Mean } \\
\text { Difference }\end{array}$} & \multirow{2}{*}{$\begin{array}{l}\text { Std. Error } \\
\text { Difference }\end{array}$} & \multicolumn{2}{|c|}{$\begin{array}{l}95 \% \text { Confidence } \\
\text { Interval of the } \\
\text { Difference }\end{array}$} \\
\hline & & & & & & & & & Lower & Upper \\
\hline \multirow[t]{2}{*}{ CD4 (\%) } & $\begin{array}{l}\text { Equal } \\
\text { variances } \\
\text { assumed }\end{array}$ & .023 & .882 & -1.894 & 13 & .081 & -7.77222 & 4.10290 & -16.63599 & 1.09154 \\
\hline & $\begin{array}{l}\text { Equal } \\
\text { variances not } \\
\text { assumed }\end{array}$ & & & -1.853 & 10.056 & .093 & -7.77222 & 4.19394 & -17.10987 & 1.56542 \\
\hline \multirow[t]{2}{*}{ CD8 (\%) } & $\begin{array}{l}\text { Equal } \\
\text { variances } \\
\text { assumed }\end{array}$ & 2.642 & .128 & -.093 & 13 & .927 & -.32833 & 3.53399 & -7.96306 & 7.30639 \\
\hline & $\begin{array}{l}\text { Equal } \\
\text { variances not } \\
\text { assumed }\end{array}$ & & & -.084 & 7.458 & .935 & -.32833 & 3.90992 & -9.45986 & 8.80320 \\
\hline \multirow[t]{2}{*}{$\mathrm{CD} 4 / \mathrm{CD} 8$} & $\begin{array}{l}\text { Equal } \\
\text { variances } \\
\text { assumed }\end{array}$ & 13.730 & .003 & -1.674 & 13 & .118 & -1.03492 & .61810 & -2.37024 & .30039 \\
\hline & $\begin{array}{l}\text { Equal } \\
\text { variances not } \\
\text { assumed }\end{array}$ & & & -1.391 & 5.583 & .217 & -1.03492 & .74409 & -2.88916 & .81931 \\
\hline
\end{tabular}

There is a statistically significant difference in the CD4 / CD8 ratio. The CD4 / CD8 ratio is increased in the group of patients undergoing radiotherapy. An additional study is needed in a larger group of patients.

For patients undergoing treatment with Transtuzumab and hormone therapy, the mean value for CD4 + Tlymphocytes was 23.78 , for CD8 +16.73 and the ratio was 1.48. For patients undergoing radiotherapy, the mean value for CD4 + T lymphocytes was 31.55 for CD8 + 17.06 and the CD4 + / CD8 + ratio was 2.51 .
Table 13 presents the statistical correlation of $\mathrm{T}$ lymphocyte values in patients receiving HT and RT treatment, and table 14 shows the mean T lymphocyte for patients undergoing treatment with Transtuzumab + HT and $\mathrm{HT}$

The higher CD4 + T and CD4 + / CD8 + ratio are observed in the group of patients undergoing radiotherapy, but statistically there are differences, but they are not statistically significant ( $p>0.05)$. 


\begin{tabular}{|c|c|c|c|c|c|}
\hline \multicolumn{2}{|c|}{ LYMPHOCYTE T } & N & Mean & Std. Deviation & Std. Error Mean \\
\hline \multirow{2}{*}{ CD4 (\%) } & 2 & 9 & 23.7844 & 7.46628 & 2.48876 \\
\cline { 2 - 6 } & 9 & 34 & 28.1724 & 6.97379 & 1.19599 \\
\hline \multirow{2}{*}{ CD8 (\%) } & 2 & 9 & 16.7333 & 5.19339 & 1.73113 \\
\cline { 2 - 6 } & 9 & 34 & 20.6638 & 6.63040 & 1.13710 \\
\hline CD4/CD8 & 2 & 9 & 1.4805 & 0.5216 & 0.1739 \\
\cline { 2 - 6 } & 9 & 34 & 1.4946 & 0.5627 & 0.0965 \\
\hline
\end{tabular}

Table 14

MEAN T LYMPHOCYTE FOR PATIENTS UNDERGOING TREATMENT WITH TRANSTUZUMAB + HT AND HT
For patients undergoing Transtuzumab + hormone therapy, the mean value for CD4 + T lymphocytes was 23.78, for CD8 + 16.73 and the ratio CD4 + / CD8 + of 1.48 .

For patients undergoing hormone therapy, the mean value for CD8 + T lymphocytes was 28.17, for CD8 + 20.06 and the CD4 + / CD8 + ratio of 1.49 .

Statistical analysis for the group of patients undergoing hormone therapy and the group of patients undergoing hormone therapy concluded that there are differences in CD4 + and CD8 + T lymphocytes, but they are not statistically significant $(p>0.05)$.

\section{Results and discussions}

In breast cancer, the extensive tumor infiltration by cytotoxic CD8 T cells was strongly associated with patient survival and response to treatment. The presence of CD4 $+T$ cells was associated with both good response to treatment and mitigation of the antitumor response [1-8]. Statistically, we did notfind a statistical correlation between TILs grade and CD4 + and CD8 + T lymphocytes analyzed from the peripheral blood.

We noticed that chemotherapy used in different types of cancer [9-13] caused a short-term decrease in the values of all major subtypes of circulating lymphocytes (3-6 months) and prolonged (> 9 months) prolongation of CD4 + T cells. This is consistent with a smaller previous study showing a sustained decrease in the CD4 + T cells, but not CD8 +, after FEC breast cancer chemotherapy [3]. CD4 + and CD8 + T cells have opposite roles in the progression of breast cancer and in its evolution. From the analysis of CD4 + T cells in relation to the presence of metastases, it was revealed that elevated CD4 + values are associated with fewer metastases.

Analysis of the relationship between TIL density and patient age demonstrated that $T$ lymphocytes and their CD4 + and CD8 + subgroups were directly associated with the age of the patient. Such a relationship has been investigated in several studies with discordant results performed by Marsigliante et al. [4] who found that only T cells were directly associated with the age of the patient, thus supporting our results in part. Instead, Menard et al. [5] did not report significant differences between the different age groups in terms of TIL frequency. More recently, Mahmoud et al. [6] showed that the CD8 + lymphocyte count was slightly inversely proportional to the age of breast cancer patients.

In the present study, the T lymphocyte analysis for patients undergoing radiotherapy indicated a mean value of $31 \%$ for CD4 + T and $17 \%$ for CD8 +, suggesting that the CD8 + T lymphocytes are more sensitive and more specific, also supported by the study of Mahmut Ozsahin et al., [7-8] which has prospectively confirmed that apoptosis of radiation-induced $T$ lymphocytes has significantly predicted late effects [14].

Previous studies have shown that the CD4 / CD8 T cell response reflects the status of the immune system and can independently predict mortality from all causes. Shah et al. [15] in their study reported that the low CD4 / CD8 ratio was significantly associated with the worse prognosis of patients with cervical carcinoma, and in the study by Chang-J uan Tao et al. in 2016, it was shown that the higher CD4 / CD8 ratio ( $\geq 1.77$ ) was associated with the free entry of the disease [16]. In the present study from the CD4 / CD8 ratio analysis for patients undergoing radiotherapy, an increase in values was observed, with an average of 2.5 .

We analyzed the CD4 + and CD8 + T lymphocytes for patients undergoing hormone treatment (Tamoxifen or Anastrozole) resulting in an average of $28.17 \%$ for CD4 + and $20.67 \%$ for CD8 + , suggesting that hormone therapy helps recover populations of lymphocytes postchemotherapy or radiotherapy, as confirmed by the study by Robinson et al. in 1999 [17].

Several studies have demonstrated the immunomodulatory properties of radiotherapy (RT). RT induces the death of the immunogenic cells (ICD), increases the MHCI expression in both normal and cancer cells, stimulates the chemotaxis and recruitment of $T$ cells and $T$ cells into the tumor by inducing intracellular adhesion molecules, cytokines and chemokines and inducing CTL primacy [1822]. The higher CD4 + T and CD4 + / CD8 + ratio was observed in the group of patients undergoing radiotherapy, but statistically there are differences, but they are not statistically significant ( $p>0.05$ ).

Chemotherapy can enhance the immune response by improving the immune effector cells or by exhaustion of the immunosuppressive populations. In breast cancer, taxanes can enhance the function of NK and T cells according to Carson et al. 2004 [16], and the increase in the TIL percentage in the neoadjuvant context [23]. Docetaxel increases Th1-associated cytokine levels, while decreasing the inflammatory markers in metastatic disease, according to Tsavaris et al. 2002 [24]. Small doses of cyclophosphamide [25] and paclitaxel [26] can induce selective exhaustion of Tregs, while docetaxel [27] and gemcitabine [28] may reduce the number of myeloidderived suppressor cells (MDSC). Paclitaxel, etoposide and 5-fluorouracil regulate the PDL-1 expression on cell lines in breast carp, thus promoting immune resistance [26]. Interference with the PD-1 / PD-L1 pathway with anti-PD1 / PD-L1 immunotherapy could counteract this effect. Hormonal therapy can modulate and the immune system, e.g., letrozole in the neoadjuvant setting, reduces intratumoral FOX-P3 Tregs [29].

\section{Conclusions}

Although it has been considered that chemotherapy has immunosuppressive effects, contrary, it has also been shown to have immunomodulatory effects. The study demonstrated that the adaptive immune system is altered after chemotherapy for at least 9 months by assessing the CD4 + T lymphocytes, CD8 + T and the CD4 + / CD8 + ratio. Additional investigations will be needed to determine whether therapy should be modified to avoid the most serious effects on the immune system. Interestingly, for patients undergoing metastatic Capecitabine treatment, $T$ cell antitumor reactivity was associated with lower 
changes in the $\mathrm{CD} 8+$ and $\mathrm{CD} 4+$ ratios between the two evaluations.

Determinations during hormonal treatment revealed that values increased after cytostatic treatment or radiotherapy. This observation suggests that hormone therapy helps in recovering lymphocyte populations after chemotherapy or radiotherapy. Hormone therapy also seems to help restore the T cell lymphocytes, thus the cellular immune response capacity, following the immune-induced immune suppression and chemotherapy. From analysis of the T lymphocyte percentages for radiotherapy patients, the mean $C D 4+T$ was 31.55 for CD8 + 17.06 and the CD4 + / CD8 + ratio was 2.51 .

\section{References}

1.ALIZADEH, D., LARMONIER, N., Cancer. Res., 74, nr. 10, 2014, p. 2663.

2.SALGADO R, DENKERT C, DEMARIA S, SIRTAINE N, KLAUSCHEN F, PRUNERI G, WIENERT S, VAN DEN EYNDEN G, BAEHNER FL, PENAULT-LLORCA F, PEREZ EA, THOMPSON EA, SYMMANS WF, RICHARDSON AL, BROCK J, CRISCITIELLO C, BAILEY H, IGNATIADIS M, FLORIS G, SPARANO J, KOS Z, NIELSEN T, RIMM DL, ALLISON KH, REIS-FILHO JS, LOIBL S, SOTIRIOU C, VIALE G, BADVE S, ADAMS S, WILLARD-GALLO K, LOI S, Annals Oncol., 26, nr. 2, 2015, p. 259-271.

3.MOZAFFARI, F., LINDEMALM, C., CHOUDHURY, A., GRANSTAMBJ ORNEKLETT, H., LEKANDER, M., NILSSON, B., et al., Cancer Immunol. Immunother., 58, nr. 1, 2009, p. 111.

4.MARSIGLIANTE, S., BISCOZZO L., MARRA, A., NICOLARDI, G., LEO, G., LOBREGLIO, G.B., et al., Cancer Lett., 139, 1999, p. 33.

5.MENARD, S., TOMASIC, G., CASALINI, P., BALSARI, A., PILOTTI, S., CASCINELLI, N., et al., Clin. Cancer Res., 3, 1997, p. 817.

6.VATNER, R., COOPER, B., VANPOUILLE-BOX, C., DEMARIA, S., FORMENTI, S. Frontiers Oncol., 4, 2014, 325.

7.GAMEIRO, S., ARDIANI, A., KWILAS, A., HODGE, J. Oncoimmunol., 2015, 3, e28643.

8.KROEMER, G., GALLUZZI, L., KEPP, O., ZITVOGEL, L., Annu. Rev. Immunol., 31, 2013, p. 51.

9.ABDEL-DAIM, M.M., ZAKHARY, N.I., ALEYA, L., BUNGAU, S.G., BOHARA, R.A., SIDDIQI, N.J ., Oxid. Med. Cell. Longev., 2018, 2018, ID 2098123, 2 pages.

10.ENDRES, L., TIT, D.M., BUNGAU, S., CIOCA, G., ABDEL-DAIM, M., BUHAS, C., POP, O., SAVA, C., Rev. Chim.(Bucharest), 69, no. 12, 2018, p. 3675

11.ABDEL-DAIM, M.M., SHAHEEN, H.M., ABUSHOUK, A.I., TORAIH, E.A., FAWZY, M.S., ALANSARI, W.S., ALEYA, L., BUNGAU S., Environ. Sci. Pollut. Res. Int., 25, nr. 24, 2018, p. 23909
12.MOGOANTA, S.S., COSTACHE, A., MUTIU, G., BUNGAU, S.G., GHILUSI, M., GROSU, F., VASILE, M., VILCEA, I.D., GHERGHINESCU, M.C., MOGOANTA, L., ION, D.A., Rom. J. Morphol. Embriol., 56, nr. 2 Suppl., 2015, p. 511.

13.PALLAG, A., ROSCA, E., TIt, D.M., MUTIU, G., BUNGAU, S.G., POP, O.L., Rom. J. Morphol. Embriol., 56, nr. 3, 2015, p. 1103.

14.OZSAHIN M. CROMPTON NE, GOURGOU S, KRAMAR A, LI L, SHI Y, SOZZI WJ , ZOUHAIR A, MIRIMANOFF RO, AZRIA D., Clin. Cancer Res., 11, nr. 20, 2005, p. 7426-33

15.SHAH, W, YAN, X., JING, L., ZHOU, Y., CHEN, H., WANG, Y., Cell. Mol. Immunol., 8, 2011, p. 59.

16.CARSON, W., SHAPIRO, C., CRESPIN, T., THORNTON, L., ANDERSEN,

B., Clin. Cancer. Res. 10, 2004, p. 3401.

17.ROBINSON, E., SEGAL, R., STRUMINGER, L. , FARAGGI, D. , EL'AD YARUM, R., MEKORI, T. Cancer, 85, 1999, p. 2073.

18.MEHEDINTU, C., BRATILA, E., BERCEANU, C., CIRSTOIU, M.M., BARAC, R. I., ANDREESCU, C.V., BADIU, D.C., GALES, L., ZGURA, A., BUMBU, A.G., Rev. Chim.(Bucharest), 69, no. 11, 2018, p.3133-3137 19.DIACONU, C.C., STANESCU, A.M.A., PANTEA STOIAN, A., TINCU, R.C., COBILINSCHI, C., DRAGOMIRESCU, R.I.F., SOCEA, B., SPINU, D.A., MARCU, D., SOCEA, L.I., BRATU, O.G., Rev. Chim.(Bucharest), 69, no. 6, 2018, p. 1367.

20.DIACONU, C.C., DRAGOI, C.M., BRATU, O.G., NEAGU, T.P., PANTEA STOIAN, A., COBELSCHI, P.C., NICOLAE, A.C., IANCU, M.A., HAINÃRO'IE, R., STANESCU, A.M.A., SOCEA, B., Farmacia, 2018, 66, nr. 3, 2018, p. 408.

21.DIACONU, C.C., MANEA, M., IANCU, M.A., STANESCU, A.M.A., SOCEA, B., SPINU, D.A., MARCU, D., BRATU, O.G., Rev. Chim.(Bucharest), 69, no. 5, 2018, p. 1071.

22.RADULESCU, D., BALCANGIU STROESCU, A., PRICOP, C., GEAVLETE, B., NEGREI, C., BRATU, O., GINGHINA, O., VACAROIU, I., Rev. Chim.(Bucharest), 68, no.1, 2017, p. 52.

23.DEMARIA, S., VOLM, M., SHAPIRO, R., YEE, H., ORATZ, R., FORMENTI, S. ET AL. Clin. Cancer Res., 7, 2001, p. 3025.

24.TSAVARIS, N., KOSMAS, C., VADIAKA, M., KANELOPOULOS, P. AND BOULAMATSIS, D., Br. J. Cancer, 87, 2002, p. 21.

25.GHIRINGHELLI, F., MENARD, C., PUIG, P., LADOIRE, S., ROUX, S., MARTIN, F., et al., Cancer Immunol. Immunother., 56, 2007, p. 641. 26.ZHANG, L., DERMAWAN, K., JIN, M., LIU, R., ZHENG, H., XU, L. et al., Clin. Immunol., 129, 2008, p. 219.

27.KODUMUDI, K., WOAN, K., GILVARY, D., SAHAKIAN, E., WEI, S., DJEU, J., Clin. Cancer. Res., 16, 2010, p. 4583.

28.NOWAK, A., ROBINSON, B., LAKE, R., Cancer Res., 62, 2002, p. 2353.

29.GENERALI, D., BATES, G., BERRUTI, A., BRIZZI, M., CAMPO, L., BONARDI, S. et al., Clin. Cancer Res., 15, 2009, p. 1046

Manuscript received: 5.12 .2018 